\title{
The Post-Bellum Recovery of the South and the Cost of the Civil War: Comment
}

\section{Citation}

Goldin, Claudia and Frank D. Lewis. 1978. The Post-Bellum recovery of the South and the cost of the Civil War: Comment. Journal of Economic History 38(2): 487-492.

\section{Published Version}

http://www.jstor.org/stable/2119842

\section{Permanent link}

http://nrs.harvard.edu/urn-3:HUL.InstRepos:2645467

\section{Terms of Use}

This article was downloaded from Harvard University's DASH repository, and is made available under the terms and conditions applicable to Other Posted Material, as set forth at http:// nrs.harvard.edu/urn-3:HUL.InstRepos:dash.current.terms-of-use\#LAA

\section{Share Your Story}

The Harvard community has made this article openly available.

Please share how this access benefits you. Submit a story.

\section{Accessibility}




\section{The Post-Bellum Recovery of the South and the Cost of the Civil War: Comment}

In a recent article in this JOURNAL we estimated the impact of the Civil War and related events, by constructing a hypothetical consumption stream-one which would have existed in the absence of the war. ${ }^{1}$ The "cost of the war" to the North and to the South was computed by comparing this consumption stream to the one actually achieved. A very large figure, especially for the South, resulted from this procedure, and we then attempted to decompose it. We attributed one large portion of the total cost to direct outlays on the conflict and a second major component to physical destruction. We suggested that much of the remaining figure was the result of factors associated with the war, such as emanicipation, trade disruption, and the demise of the plantation economy.

Peter Temin has criticized our procedure in "The Post-Bellum Recovery of the South and the Cost of the Civil War," by focusing on two possible components of our cost to the South. The first is the decline in work effort of former slaves, and the second is the retardation in the demand for cotton as calculated by Gavin Wright. ${ }^{2}$ Our paper contains an explicit estimate of the first cost, for which our upper bound value of $\$ 1.96$ billion is only 21 percent of our estimated total cost to the South. ${ }^{3}$ We did not detail the second component, and according to Temin, our neglect of this has led to our overstating the cost of the Civil War to the South by a factor of four. Temin's conclusion, however, is not based on an explicit calculation using Wright's data. He assumes, instead, that even in the absence of the Civil War per capita consumption would have fallen to its actual 1879 level of $\$ 62.03$ instead of increasing to $\$ 110.48$, as we assumed. ${ }^{4}$ Temin justifies this conclusion by stating that "the wartime devastation in the South had been repaired long before the end of the 1870 's, ... . [therefore] there does not seem any reason to assert that the level of southern income and consumption was depressed after 1879 because of the Civil War."5

Journal of Economic History, Vol. XXXVIII, No. 2 (June 1978). Copyright (C) The Economic History Association. All rights reserved.

We thank Gavin Wright for his comments.

1 C. Goldin and F. Lewis, "The Economic Cost of the American Civil War: Estimates and Implications," The Journal OF ECONOMIC History, 35 (June 1975), 299-326. Note that we do not claim to be measuring only the cost of destruction from the Civil War but also the costs of related events, such as emancipation. The title of our original paper has misled some readers, and we emphasize here that we are using the phrase "economic cost of the Civil War" very broadly.

2 P. Temin, "The Post-Bellum Recovery of the South and the Cost of the Civil War," ThE Journal of Economic History, 36 (Dec. 1976), 898-907, and G. Wright, "Cotton Competition and the Post-Bellum Recovery of the American South," ThE Journal OF ECONOMIC HistoRY, 34 (Sept. 1974), 610-35.

3 Goldin and Lewis, "Economic Costs," pp. 315 and 317.

4 Temin, "Post-Bellum Recovery," p. 906.

5 Ibid., p. 905. Temin's assumption about hypothetical consumption in 1879 is not only ad 
Rather than assume full recovery by 1879 as does Temin, we have explicitly estimated the impact on hypothetical southern consumption of the supposed slowdown in world demand for cotton. Our calculation does not indicate that we have greatly inflated the costs attributable to factors associated with the Civil War, but reasserts our initial conclusion that such costs were very large.

The value of southern cotton production in 1859 was $\$ 197.6$ million or $\$ 23.15$ per capita, and it grew from 1839 to 1859 , at a per capita rate of 3.56 percent per year. ${ }^{6}$ Had that growth rate continued after 1859 , the value of cotton output in 1879 would have been $\$ 46.64$ per capita or $\$ 596.9$ million for the entire South. Gavin Wright's research indicates, however, that the actual level of demand did not increase at its prewar rate and was only 46 percent of what would have been achieved in 1879 had demand continued to increase at that rate. In per capita terms demand in 1879 was only 49 percent of its hypothetical level. ${ }^{7}$ Our estimate of the loss in consumption from this retardation in cotton demand is computed by comparing the actual demand for cotton to a hypothetical demand, one growing at the prewar rate, and computing the difference in income between these two cases for 1879 .

The market for cotton in 1879 is depicted in Figure 1, where $D^{\text {h }}$ is the hypothetical cotton demand curve assuming the (per capita) prewar demand shift continued; $\mathrm{D}^{\mathrm{a}}$ is the actual cotton demand curve, assuming Wright's data are correct; and $S$ is the cotton supply curve. The shaded area, $\mathbf{P}^{\mathbf{0}} \mathbf{P}^{\mathbf{1}} \mathbf{B A}$, represents the impact on hypothetical income in the South of the reduction in the rate of increase in cotton demand. If the supply and demand curves

hoc but is also contradicted by some facts about the capital stock. In 1860 the (non-slave) capital stock was $\$ 3.485$ billion, that is $\$ 399$ per capita. Our estimate for 1870 is $\$ 2.477$ billion and the 1880 Federal Census gives a value for the capital stock of $\$ 4.506$ billion or $\$ 346$ per capita. The 1880 per capita figure is 13 percent less than that for 1860 and far less than a hypothetical value which assumes the capital stock would have continued to grow at its prewar rate. (See Goldin and Lewis, "Economic Cost," accompanying "Notes," pp. xvii-xix. All values are expressed in 1860 dollars.)

6 Robert Gallman, “Commodity Output, 1839-1899," in National Bureau of Economic Research, Trends in the American Economy in the Nineteenth Century, Studies in Income and Wealth, vol. 24 (Princeton, 1960), pp. 43 and 46. All values are in 1860 dollars.

7 The prewar demand curve estimated by Wright is:

$$
\mathrm{Q}=\mathrm{kP}^{-1.099} \text {, where } \mathrm{k}=\mathrm{k}^{*} \mathrm{e}^{0.054 t}
$$

(Wright, “Cotton Competition," p. 631, Table 7, assumption 1). Between 1859 and 1879 cotton output increased by 21.4 percent and its relative price increased by 6.5 percent (Gallman, "Commodity Output, 1839-1899," pp. 43, 46 and 47). By applying Wright's estimate of the elasticity of cotton demand, -1.099 , we derive an actual increase in the level of cotton demand of 30 percent over this period. However, if one extrapolates the prewar demand curve forward for 20 years, (at 5.4 percent per year) one gets a hypothetical level of demand in 1879 which is 186 percent greater than the 1859 level. Therefore the actual level of demand in 1879 was only 45 percent of its hypothetical value. This same calculation in per capita terms results in a larger figure because the rate of population growth in the South fell after 1859. Note that converting demand curve shifts to per capita terms changes only slightly the relationship between actual and hypothetical demand. In no way does this conversion imply a dependence of cotton demand on southern population growth. Furthermore, the per capita value, 49 percent, is appropriate for our purpose since in our original article the hypothetical consumption stream was based on per capita prewar growth rates. 


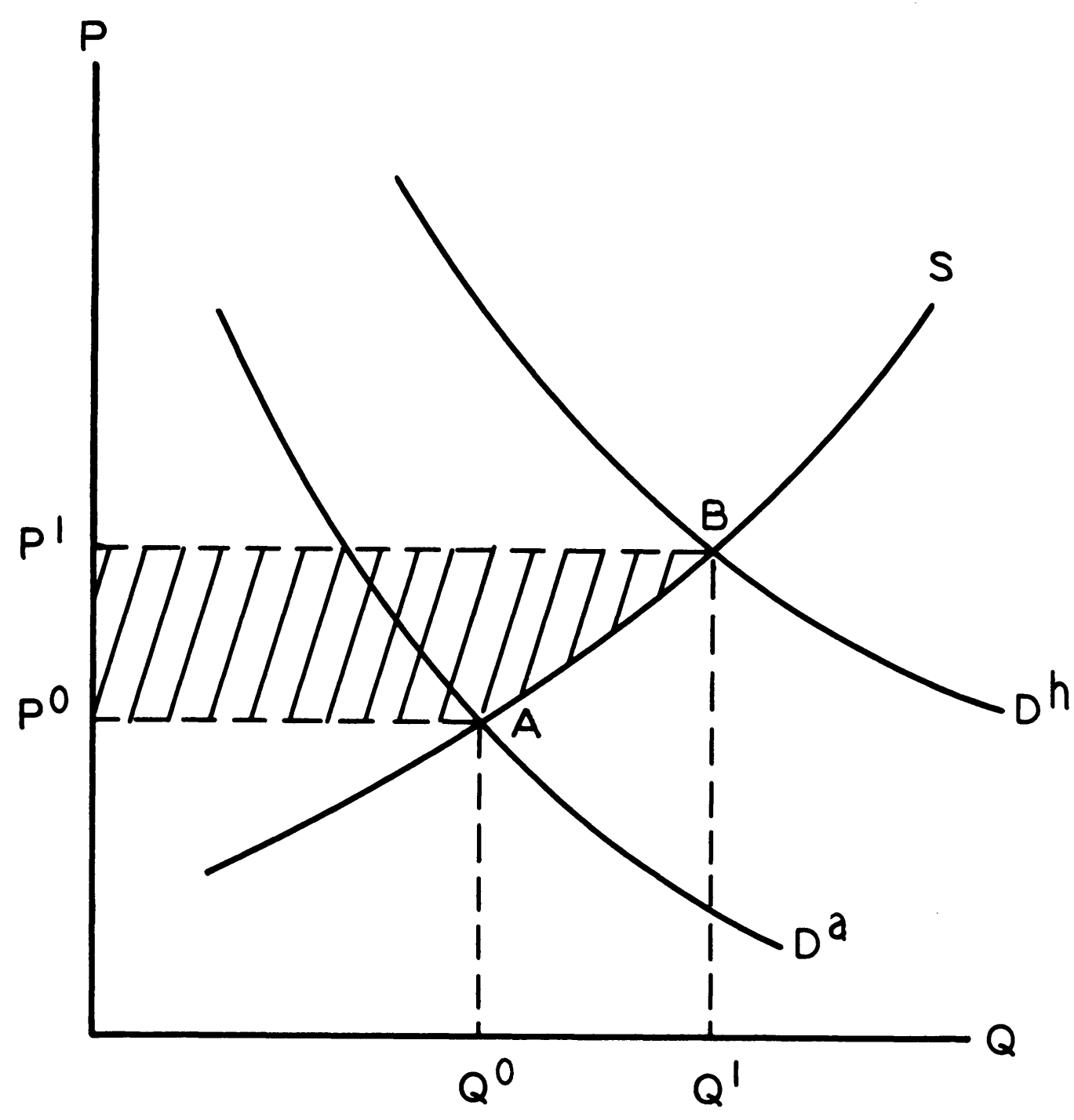

Figure 1

THE MARKET FOR COTTON

are assumed to be of constant elasticity, this area can be expressed as:

$$
\Delta \mathrm{Y}=\frac{\mathrm{P}^{1} \mathrm{Q}^{1}}{\gamma+1}\left[\left(\frac{\mathrm{d}^{\mathrm{a}}}{\mathrm{d}^{\mathrm{h}}}\right)^{\frac{\gamma \div 1}{\gamma \div \eta}}-1\right]^{\mathbf{8}}
$$

where $\eta, \gamma=$ elasticity of demand (absolute value), supply of cotton, $\mathrm{d}^{\mathrm{a}, \mathrm{h}}=$ actual, hypothetical level of demand for cotton, $\Delta \mathrm{Y}=$ change in income.

8 This equation is derived by integrating over the supply curve. For a similar derivation see Goldin and Lewis, "The Role of Exports in American Economic Growth during the Napoleonic Wars, 1793 to 1807," in R. Caves, D. North, and J. Price, editors, Exports and Growth in Economic History (Princeton: Princeton University Press, forthcoming). 
Substituting the hypothetical value of cotton in $1879, \mathrm{P}^{1} \mathrm{Q}^{1}$, and the percentage of the hypothetical level of demand actually achieved, $\left(\frac{d^{a}}{d^{\mathbf{k}}}\right)$, gives:

$$
\Delta \mathrm{Y}=\left(\frac{\$ 596.9 \text { million }}{\gamma+1}\right)\left[(0.4943)^{\frac{\gamma+1}{\gamma+\eta}}-1\right] .
$$

Our estimates of $\Delta \mathrm{Y}$ given in Table 1 are based on Wright's calculation of the prewar elasticity of cotton demand (1.099) and are computed for three values of $\gamma$.

TABLE 1

THE IMPACT ON INCOME IN THE SOUTH (1879) OF THE DECLINE IN THE RATE OF GROWTH OF COTTON DEMAND (for three cotton supply elasticities)

\begin{tabular}{lrrrr}
\hline & & & & Temin's \\
& $\gamma=0$ & $\gamma=1$ & $\gamma=3.5$ & Estimate \\
$\Delta \mathrm{Y}$ (millions) & $-\$ 282.50$ & $-\$ 145.90$ & $-\$ 66.10$ & \\
$\begin{array}{l}\Delta \mathrm{Y} \text { per capita } \\
\text { Revised hypothetical }\end{array}$ & -22.08 & -11.40 & -5.16 & \\
per capita consumption $^{\text {a }}$ & 88.40 & 99.08 & 105.32 & 62.03 \\
\hline
\end{tabular}

a Our original estimate of hypothetical per capita consumption was $\$ 110.48$. It is assumed that the loss in income caused an equal loss in consumption.

We can now recompute the "indirect cost of the Civil War," that is, the value of foregone consumption discounted to 1860 from the Civil War and related events, using Temin's assumption that the prewar demand for cotton grew at Wright's estimated post-war rate. All that is required is a hypothetical per capita consumption stream, and to compute this we have assumed that the 1860 to 1879 rate of growth implied by the figures in Table 1 would have continued to 1899 . The post- 1899 growth rate is assumed to be equal to the pre-Civil War rate. The results of this computation are given in Table 2.

TABLE 2

REVISED "INDIRECT COST OF THE CIVIL WAR" TO THE SOUTH (excluding cost due to loss of life)

\begin{tabular}{cc} 
Supply Elasticity & Cost (billions of $1860 \$$ in 1861$)$ \\
$\gamma=0$ & 5.3100 \\
$\gamma=1$ & 7.2957 \\
$\gamma=3.5$ & 8.4970 \\
Our Original Estimate & $8.9695^{\mathrm{a}}$ \\
Temin's Estimate & $2.1596^{\mathrm{b}}$ \\
\hline
\end{tabular}

a This figure is from Table 5 of Goldin and Lewis, "The Economic Cost," p. 314.

b This is Temin's per capita cost multiplied by the population of the South in 1860 . 
Contrary to Temin's conclusion, Wright's findings on cotton demand do not substantially alter our calculations. We did not magnify the economic cost attributable to the Civil War by four times. Even the extreme case of $\gamma=0$ does not reverse the main qualitative findings of our paper. The more reasonable values of $\gamma=1$ and $\gamma=3.5$ generate essentially the same results. Furthermore, these revised estimates of the cost of the war are almost certainly biased downward for the following three reasons.

1. We have assumed that the entire reduction in the rate of growth in cotton demand (including the domestic demand) was completely independent of the war.

2. We have not included the increase in consumers' surplus to southern cotton consumers, resulting from the lower cotton price. These two biases are probably quite small, but a third may not be.

3. We have assumed that had the value of cotton production per capita continued to grow at its prewar rate, 3.56 percent per year, then per capita consumption in the South would have grown at its prewar rate, 1.30 percent per year. Between 1839 and 1859 cotton's income share increased from 17 percent to about 27 percent. Therefore had per capita cotton output increased after the war at its prewar rate, the growth of per capita southern income would almost certainly have accelerated. ${ }^{9}$

TABLE 3

COMPONENTS OF THE “INDIRECT COST OF THE CIVIL WAR" TO THE SOUTH

Indirect Cost (billions of $1860 \$$ in 1861)

(1) Direct Cost

(2) Cost due to Emancipation

(3) Cost due to the Decline in Rate of

Growth in Demand for Cotton

(4) Residual $9.48^{\mathrm{a}}$

$3.29[34.7]^{\mathrm{b}}$

$1.96[20.7]$

$1.67^{\mathrm{c}}[17.6]$

$2.56[27.0]$

a This includes the cost due to loss of life.

b Terms in brackets indicate the percentage of the indirect cost.

c This value corresponds to an elasticity of supply of cotton equal to one.

Source: Goldin and Lewis, "The Economic Cost," pp. 308, 315, and 317.

We can now divide our measure of the "indirect cost of the Civil War" into four main components: the direct cost of the war including physical and human capital destruction, the cost due to a reduction in the labor supply of freedmen, that is due to emancipation, the cost due to the decline in the rate of growth in demand for cotton, and a residual. ${ }^{10}$ Our allocation of these

9 For example, if we assume that both the value of cotton and non-cotton outputs had each continued to grow at their per capita prewar rates, then per capita consumption would have increased at 1.62 percent per year, not at 1.30 percent per year as we have assumed in our paper. Per capita consumption in 1879 would then have been $\$ 117.40$. Reducing this figure by the effect of the slowdown in cotton demand from Wright's data gives the following results:

Hypothetical

per capita

$$
\gamma=0 \quad \gamma=1 \quad \gamma=3.5
$$

Our Original Estimate

consumption

$95.32 \quad 106.00 \quad 112.25$

110.48

in 1879

10 Note that this does not imply that the retardation in the demand for cotton was caused by 
costs is given in Table 3. Despite the fact that components (2) and (3) are almost certainly overstated, the residual is still large -27 percent of our original indirect cost. When we combine the residual with the direct cost of the war, we are forced to conclude that although the two factors discussed by Temin played a role in depressing income after 1865, the enormous cost incurred by the South in terms of reduced consumption should be attributed primarily to factors associated with the war.

Claudia Goldin, Princeton University FranK D. LEWIS, Queen's University, Ontario

the Civil War. This is merely a convenient way of allocating our original measure, the indirect cost of the war. These four factors, related or not to the war, all resulted in lower per capita consumption. 